Available online on 15.10.2019 at http://ajprd.com
(c) 2013-19, publisher and licensee AJPRD, This is an Open Access article which permits unrestricted non-
commercial use, provided the original work is properly cited

Open 0 Access

Review Article

\title{
Stem Cell Therapy- An Overview
}

\section{Jagiri Aishwarya Goud*, Gotte Priyanka, Singireddy Swetha, Kadarla Rohith Kumar}

Department of Pharmacy Practice, Sree Chaitanya Institute of Pharmaceutical Sciences, Thimmapur, Karimnagar, Telangana, India.

\section{A B S T R A C T}

Stem cells are defined as cells that have clonogenic and self-renewing capabilities and differentiate into multiple cell lineages. Stem cells are found in all of us, from the early stages of human development to the end of life. According to differentiation potential stem cells are divided into 5 types: totipotent, pluripotent, multipotent, oligopotent and unipotent. They are vital to the development, growth, maintenance, and repair of our brains, bones, muscles, nerves, blood, skin, and other organs. Stem cell therapy is emerging as a potentially revolution- ary new way to treat disease and injury, with wide-ranging medical benefits. Stem cell research presents many ethical and scientific questions as well as future challenges. Stem cell therapy, a prologue to an era of medical discovery of cell-based therapies that will one day restore function to those whose lives are now challenged every day, is still at the beginning of the road. . Stem cells have great potential in tissue regeneration and repair but much still needs to be learned about their biology, manipulation and safety before their full therapeutic potential can be achieved.

Keywords: Stem cells, cell-based therapies, tissue regeneration.

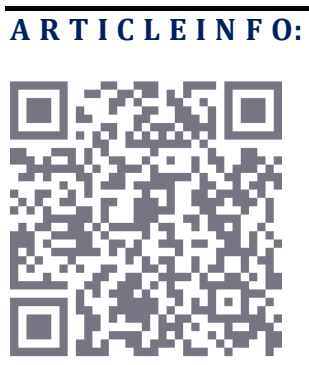

Review Completed 27 July 2019; $\quad$ Accepted 10 Oct. 2019;

Available online 15 Oct. 2019

\section{Cite this article as:}

Jagiri AG, Gotte P, Singireddy S, Kadarla R K, Stem Cell Therapy- An Overview, Asian Journal of Pharmaceutical Research and Development. 2019; 7(5):92-102, DOI: http://dx.doi.org/10.22270/ajprd.v7i5.558

\section{*Address for Correspondence:}

Dr. Rohith Kumar Kadarla, Asst Professor, Department of Pharmacy Practice, Sree Chaitanya Institute of Pharmaceutical

Sciences, Thimmapur, Karimnagar, Telangana, India

\section{INTRODUCTION}

0 tem cells are defined as cells that have clonogenic and self-renewing capabilities and differentiate into multiple cell lineages. Stem cells are found in all of us, from the early stages of human development to the end of life. Stem cells are unspecialized cells that develop into the specialized cells that make up the different types of tissue in the human body. They are characterized by the ability to renew themselves through mitotic cell division and differentiating into a diverse range of specialized cell types. They are vital to the development, growth, maintenance, and repair of our brains, bones, muscles, nerves, blood, skin, and other organs. While stem cell- based treatments have been established as a clinical standard of care for some conditions, such as hematopoietic stem cell transplants for leukemia and epithelial stem cell-based treatments for burns and corneal disorders, the scope of potential stem cell-based therapies has expanded in recent years due to advances in stem cell research. It has been only recently that scientists have understood stem cells well enough to consider the possibilities of growing them outside the body for long periods of time. With that advance, rigorous experiments can be conducted, and the possibility of manipulating these cells in such a way that specific tissues can be grown is real ${ }^{1}$.

\section{TYPES:}

They are divided into two groups being embryonic and nonembryonic (known as adult stem cells). According to differentiation potential stem cells are divided into 5 types: totipotent, pluripotent, multipotent, oligopotent and unipotent ${ }^{2}$. Totipotent stem cells can differentiate into 
embryonic as well as to extraembryonic cell types. Pluripotent stem cells give rise to any cell types of endoderm, mesoderm and ectoderm, whereas multipotent stem cells differentiate to any cell type of mainly closely related cell family. Oligopotent and unipotent stem cells have differentiation potential towards few cell types and only one type of the cells, respectively ${ }^{3}$.

\section{Totipotent}

The ability to differentiate into all possible cell types. Examples are the zygote formed at egg fertilization and the first few cells that result from the division of the zygote ${ }^{1}$.

\section{Pluripotent}

The ability to differentiate into almost all cell types. Examples include embryonic stem cells and cells that are derived from the mesoderm, endoderm, and ectoderm germ layers that are formed in the beginning stages of embryonic stem cell differentiation ${ }^{1}$.

\section{Multipotent}

The ability to differentiate into a closely related family of cells. Examples include hematopoietic (adult) stem cells that can become red and white blood cells or platelets ${ }^{1}$.

\section{Oligopotent}

The ability to differentiate into a few cells. Examples include (adult) lymphoid or myeloid stem cells ${ }^{1}$.

\section{Unipotent}

The ability to only produce cells of their own type, but have the property of self- renewal required to be labeled a stem cell. Examples include (adult) muscle stem cells ${ }^{4}$.

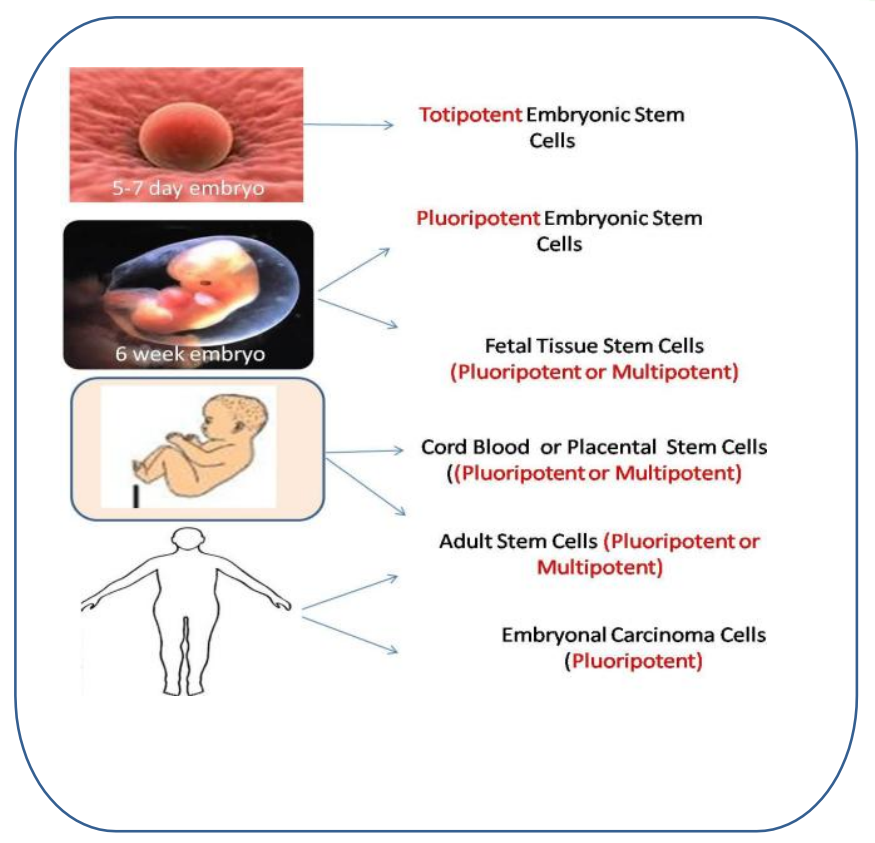

Figure 1: Classification of stem cell on basis of potency
Table 1: Characteristics of Different Types of Stem Cells ${ }^{33}$ :

\begin{tabular}{|c|c|c|}
\hline ESC & iPSC & SSC \\
\hline $\begin{array}{l}\text { Derived from inner } \\
\text { cell mass of } \\
\text { blastocyst }\end{array}$ & $\begin{array}{l}\text { Derived from } \\
\text { somatic cells }\end{array}$ & $\begin{array}{l}\text { Isolated from postnatal } \\
\text { adult tissue }\end{array}$ \\
\hline Allogenic material & $\begin{array}{l}\text { Autologous or } \\
\text { allogenic material }\end{array}$ & $\begin{array}{l}\text { Autologous or allogenic } \\
\text { material }\end{array}$ \\
\hline Pluripotent & Pluripotent & Multipotent \\
\hline $\begin{array}{l}\text { Can differentiate in } \\
\text { cell types of all three } \\
\text { germ lineages }\end{array}$ & $\begin{array}{l}\text { Can differentiate in } \\
\text { cell types of all three } \\
\text { germ lineages }\end{array}$ & $\begin{array}{l}\text { Can differentiate in } \\
\text { limited cell types } \\
\text { depending on the tissue } \\
\text { of origin }\end{array}$ \\
\hline $\begin{array}{l}\text { Ability to form } \\
\text { chimeras }\end{array}$ & $\begin{array}{l}\text { Ability to form } \\
\text { chimeras (maybe } \\
\text { more difficult than } \\
\text { for ESCs) }\end{array}$ & Cannot form chimeras \\
\hline Self-renewal & Self-renewal & Limited self-renewal \\
\hline $\begin{array}{l}\text { Require many steps } \\
\text { to drive } \\
\text { differentiation into } \\
\text { the desired cell type } \\
\text { helpe }\end{array}$ & $\begin{array}{l}\text { Require many steps } \\
\text { to manufacture (e.g. } \\
\text { genetic modification) } \\
\text { and to drive } \\
\text { differentiation into } \\
\text { the desired cell type }\end{array}$ & $\begin{array}{l}\text { Difficult to maintain in } \\
\text { cell culture for long } \\
\text { periods }\end{array}$ \\
\hline $\begin{array}{l}\text { High degree of } \\
\text { proliferation once } \\
\text { isolated }\end{array}$ & $\begin{array}{l}\text { High degree of } \\
\text { proliferation }\end{array}$ & $\begin{array}{l}\text { Ease of access, yield and } \\
\text { purification varies, } \\
\text { depending on the source } \\
\text { tissue }\end{array}$ \\
\hline Indefinite growth & Indefinite growth & $\begin{array}{l}\text { Limited lifespan } \\
\text { (population doublings) }\end{array}$ \\
\hline $\begin{array}{l}\text { Production of } \\
\text { endless number of } \\
\text { cells Chromosome } \\
\text { length is maintained } \\
\text { across serial passage }\end{array}$ & $\begin{array}{l}\text { Production of } \\
\text { endless number of } \\
\text { cells Chromosomes } \\
\text { tend to shorten with } \\
\text { ageing }\end{array}$ & $\begin{array}{l}\text { Production of endless } \\
\text { number of cells } \\
\text { Chromosomes tend to } \\
\text { shorten with ageing }\end{array}$ \\
\hline $\begin{array}{l}\text { Significant teratoma } \\
\text { risk }\end{array}$ & $\begin{array}{l}\text { Significant teratoma } \\
\text { risk }\end{array}$ & No teratoma risk \\
\hline Serious ethical issues & No ethical issues & No ethical issues \\
\hline $\begin{array}{l}\text { Immuno-priviliged. } \\
\text { Low level of MHC I } \\
\text { and II (also in ESC- } \\
\text { derived cells) }\end{array}$ & $\begin{array}{l}\text { Not immuno- } \\
\text { priviliged when } \\
\text { derived from adult } \\
\text { cells. Normal level } \\
\text { of MHC I and II } \\
\text { molecules. }\end{array}$ & $\begin{array}{l}\text { MSC have low } \\
\text { immunogenicity and are } \\
\text { immunomodulatory. Not } \\
\text { known for other somatic } \\
\text { SC. }\end{array}$ \\
\hline $\begin{array}{l}\text { Cell lines will be } \\
\text { allogenic }\end{array}$ & $\begin{array}{l}\text { Less chance immune } \\
\text { rejection in case of } \\
\text { HLAmatching }\end{array}$ & $\begin{array}{l}\text { In case of autologous use, } \\
\text { less chance of immune } \\
\text { rejection, but } \\
\text { immunogenicity in } \\
\text { allogenic and } \\
\text { nonhomologous } \\
\text { applications remains } \\
\text { unpredictable }\end{array}$ \\
\hline $\begin{array}{l}\text { Donor history may } \\
\text { be unknown for 'old' } \\
\text { cell lines (i.e. } \\
\text { initially not intended } \\
\text { for clinical } \\
\text { application) }\end{array}$ & $\begin{array}{l}\text { Targeted disease } \\
\text { may still be present } \\
\text { in stem cell in case } \\
\text { of autologous use }\end{array}$ & $\begin{array}{l}\text { Targeted disease may still } \\
\text { be present in stem cell in } \\
\text { case of autologous use }\end{array}$ \\
\hline
\end{tabular}


The easiest way to categorize stem cells is by dividing them into two types: Early or embryonic and mature or adult. Early stem cells, often called embryonic stem cells, are found in the inner cell mass of a blastocyst after approximately five days of development. Mature stem cells are found in specific mature body tissues as well as the umbilical cord and placenta after birth ${ }^{5}$.

\section{STEM CELL THERAPY ${ }^{6}$}

\section{Pluripotent stem cells}

Pluripotent stem cells have not yet been used therapeutically in humans because many of the early animal studies resulted in the undesirable formation of unusual solid tumors, called teratomas. Teratomas are made of a mix of cell types from all the early germ layers. Later successful animal studies used pluripotent cells modified to a more mature phenotype which limits this proliferative capacity. Cells derived from pluripotent cells have been used to successfully treat animals. For example, animals with diabetes have been treated by the creation of insulin-producing cells responsive to glucose levels. Also, animals with acute spinal cord injury or visual impairment have been treated by creation of new myelinated neurons or retinal epithelial cells, respectively. Commercial companies are currently in negotiations with the FDA regarding the possibility of advancing to human trials. Other animal studies have been conducted to treat several maladies such as Parkinson's disease, muscular dystrophy and heart failure ${ }^{7,8,9}$.

Scientists hope that stem cell therapy can improve cardiac function by integration of newly formed beating cardiac myocytes into the myocardium to produce greater force. Patches of cardiac myocytes derived from human embryonic stem cells can form viable human myocardium after transplantation into animals ${ }^{10}$ with some showing evidence of electrical integration. ${ }^{11,12}$ Damaged rodent hearts showed slightly improved cardiac function after injection of cardiac myocytes derived from human embryonic stem cells ${ }^{13}$, The mechanisms for the gain in function are not fully understood but it may be only partially due to direct integration of new beating heart cells. It is more likely due to paracrine effects that benefit other existing heart cells.

\section{Multipotent stem cells}

Multipotent stem cells harvested from bone marrow have been used since the 1960's to treat leukemia, myeloma and lymphoma. Since cells there give rise to lymphocytes, megakaryocytes and erythrocytes, the value of these cells is easily understood in treating blood cancers. Recently, some progress has been reported in the use of cells derived from bone marrow to treat other diseases. For example, the ability to form whole joints in mouse model ${ }^{\mathrm{s}^{14}}$ has been achieved starting with mesenchymal stem cells that give rise to bone and cartilage. In the near future multipotent stem cells are likely to benefit many other diseases and clinical conditions. Bone marrow-derived stem cells are in clinical trials to remedy heart ailments. This is discussed in detail in the next review of this series.

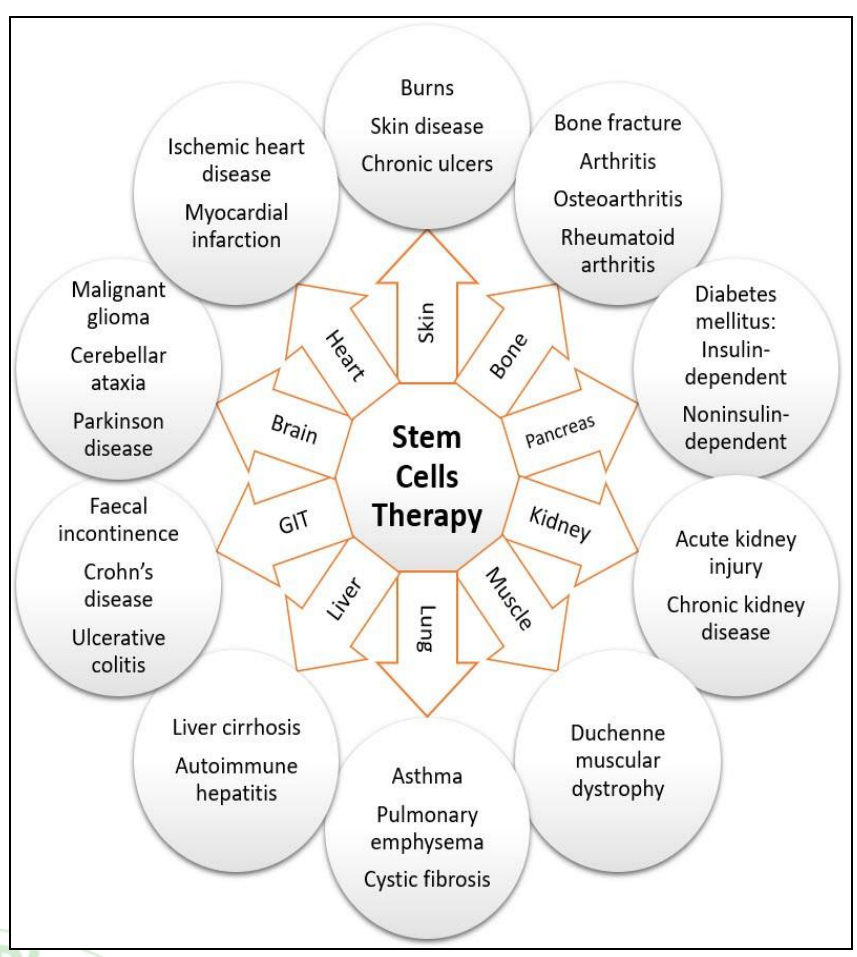

\section{APPLICATIONS OF STEM CELLS ${ }^{\mathbf{1}}$ :}

The goal of any stem cell therapy is to repair a damaged tissue that can't heal itself. Ongoing research on stem cell therapies gives hope to patients who would normally not receive treatment to cure their disease but just to alleviate the symptoms of their chronic illness. Stem cell therapies involve more than simply transplanting cells into the body and directing them to grow new, healthy tissue. It may also be possible to coax stem cells already in the body to work overtime and produce new tissue.

\section{Possible Treatments by Stem Cells:}

A number of stem cell therapeutics exist, but most are at experimental stages and/or costly, with the notable exception of bone marrow transplantation. Medical researchers anticipate that adult and embryonic stem cells will soon be able to treat cancer, Type 1 diabetes mellitus, Parkinson's disease, Huntington's disease, Celiac Disease, cardiac failure, muscle damage and neurological disorders, and many others ${ }^{15}$. They have suggested that before stem cell therapeutics can be applied in the clinical setting, more research is necessary to understand stem cell behavior upon transplantation as well as the mechanisms of stem cell interaction with the diseased/injured microenvironment.

Bone marrow transplants (BMT) are a well known clinical application of stem cell transplantation. BMT can repopulate the marrow and restore all the different cell types of the blood after high doses of chemotherapy and/or radiotherapy, our main defense used to eliminate endogenous cancer cells. 
The isolation of additional stem and progenitors cells is now being developed for many other clinical applications.

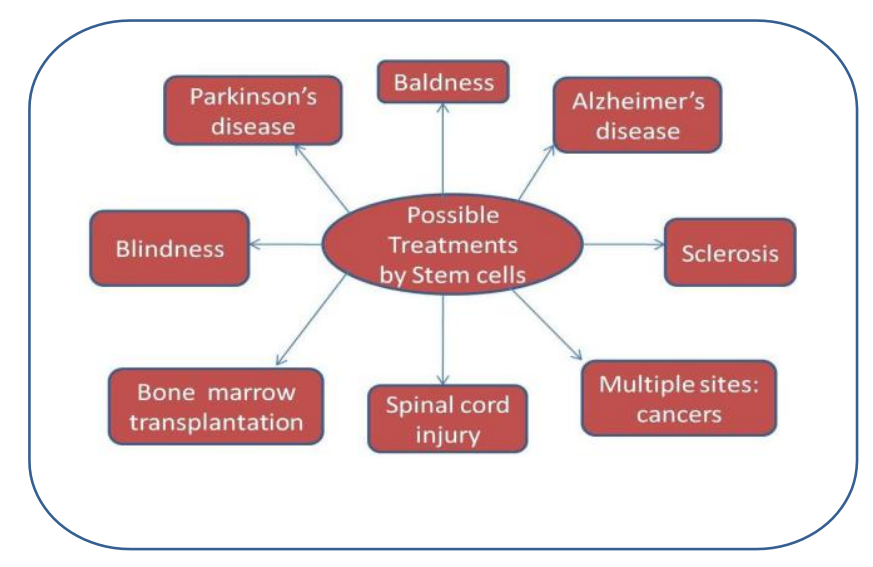

Figure 3: Possible treatments by stem cells

\section{Skin replacement}

The knowledge of stem cells has made it possible for scientists to grow skin from a patient's plucked hair. Skin (keratinocyte) stem cells reside in the hair follicle and can be removed when a hair is plucked ${ }^{16}$. These cells can be cultured to form an epidermal equivalent of the patients own skin and provides tissue for an autologous graft, bypassing the problem of rejection.

\section{Brain cell transplantation}

Stem cells can provide dopamine - a chemical lacking in victims of Parkinson's disease. It involves the loss of cells which produce the neurotransmitter dopamine. The first double-blind study of fetal cell transplants for Parkinson's disease reported survival and release of dopamine from the transplanted cells and a functional improvement of clinical symptoms ${ }^{17}$. However, some patients developed side effects, which suggested that there was an over sensitization to or too much dopamine. Although the unwanted side effects were not anticipated, the success of the experiment at the cellular level is significant.

\section{Treatment for diabetes}

Diabetes affects millions of people in the world and is caused by the abnormal metabolism of insulin. Normally, insulin is produced and secreted by the cellular structures called the islets of langerhans in the pancreas. Recently, insulin expressing cells from mouse stem cells have been generated $^{18}$. In addition, the cells self assemble to form structures, which closely resemble normal pancreatic islets and produce insulin. Future research will need to investigate how to optimize conditions for insulin production with the aim of providing a stem cell-based therapy to treat diabetes to replace the constant need for insulin injections.

\section{Rebuilding the nervous system with stem cells ${ }^{19}$}

The past decade has seen impressive advances in the prevention and treatment of cerebrovascular disease. Several new therapies are under investigation to address the longterm disability of stroke survivors. Stem cell therapy offers exciting potential for ambitious cellular replacement to treat diseases such as Parkinson's disease, Alzheimer's disease or even replacement of the cell death that follows thromboembolic stroke. Longer-term safety and efficacy results should enhance our understanding of cell implantation therapy for the treatment of stroke.

\section{Spinal Cord Disorders ${ }^{20}$}

Clinicians and scientists in the field of spinal cord injury research and medicine are poised to begin translating promising new experimental findings into treatments for people. Advances in stem cell research have led to several transplantation strategies that promote axonal regrowth and partial functional recovery in spinal cord injury. Christopher Reeve Paralysis Foundation (CRPF) funds research to treat or cure paralysis resulting from spinal cord injury or other CNS disorders. CPRF supports a Research Consortium, focus on stem cells, making a lot of progress

\section{Can Stem Cells Repair a Damaged Heart?}

For those suffering from common, but deadly, heart diseases, stem cell biology represents a new medical frontier. Researchers are working toward using stem cells to replace damaged heart cells and literally restore cardiac function

Recent interest has focused on myocardial regeneration with stem-cell transplantation as a possible treatment option to reverse the deleterious hemodynamic and neurohormonal effects that occur after myocardial infarction and can lead to congestive heart failure..

Recently the BOOST trial (Bone marrow transfer to enhance ST-elevation infarct regeneration) has confirmed an increase in global LVEF by $6.7 \%$ in 6 months follow up study ${ }^{21}$. Similar studies have been conducted recently in India at AIIMS.

Future randomized clinical trials will establish the magnitude of the benefit and the effects on arrhythmias after stem-cell therapy ${ }^{22}$.

\section{Stem Cell Therapy for HIV ${ }^{23}$}

The hematopoietic stem cell has long been hypothesized to be a target of human immunodeficiency virus type-1 (HIV) infection that limits the potential for compensatory immune cell production.

Data have recently emerged documenting stem cell dysfunction in HIV disease and indicating that immune recovery from potent antiretroviral therapy is partly driven by new T-cell generation.

Effects of HIV on stem cell physiology, however, appear to be indirect, as stem cells are highly resistant to HIV infection. Despite the presence of surface receptors for HIV, the hematopoietic stem cell is not infectible with HIV and can serve as a resource for cellular therapies for AIDS. 


\section{Orthopedics}

It is now possible to repair articular cartilage using the patient's own articular chondrocytes retrieved during arthroscopy and expanded in vitro.

Pulmonary medicine: cystic fibrosis, idiopathic pulmonary fibrosis, lung transplantation are the recent areas of pursuit.

Ophthalmology: Stem cells hold promise to retinal degeneration, glaucoma and corneal disorders.

\section{How Stem Cell Transplants Work against Cancer $^{34}$ ?}

Stem cell transplants do not usually work against cancer directly. Instead, they help you recover your ability to produce stem cells after treatment with very high doses of radiation therapy, chemotherapy, or both.

However, in multiple myeloma and some types of leukemia, the stem cell transplant may work against cancer directly. This happens because of an effect called graft-versus-tumor that can occur after allogeneic transplants. Graft-versustumor occurs when white blood cells from your donor (the graft) attack any cancer cells that remain in your body (the tumor) after high-dose treatments. This effect improves the success of the treatments.

\section{SOURCES:}

\section{Embryonic stem cells}

Embryonic stem cells are self- replicating pluripotent cells that are potentially immortal ${ }^{24}$. They are derived from embryos at a developmental stage before the time of implantation would normally occur in the uterus ${ }^{25}$. The embryos from which human embryonic stem cells are derived are typically four or five days old and are a hollow microscopic ball of cells called the blastocyst ${ }^{26}$.

\section{Adult stem cells}

Adult stem cells are undifferentiated totipotent or multipotent cells, found throughout the body after embryonic development, which multiply by cell division to replenish dying cells and regenerate damaged tissues. The primary roles of adult stem cells in a living organism are to maintain and repair the tissue in which they are found. Unlike embryonic stem cells, which are defined by their origin (the inner cell mass of the blastocyst), the origin of adult stem cells in some mature tissues is still under investigation $^{27}$.

\section{Pluripotent stem cells}

Recently, a third type of stem cell, with properties similar to embryonic stem cells, has emerged. Scientists have engineered these induced pluripotent stem cells ${ }^{\mathrm{i}}$ (iPS cells) by manipulating the expression of certain genes 'reprogramming' somatic cells back to a pluripotent state ${ }^{28-30}$.

\section{Stem Cell Culture}

Growing cells in the laboratory is known as cell culture. Human embryonic stem cells (hESCs) are generated by transferring cells from a preimplantation- stage embryo into a plastic laboratory culture dish that contains a nutrient broth known as culture medium. The cells divide and spread over the surface of the dish. However, if the plated cells survive, divide and multiply enough to crowd the dish, they are removed gently and plated into several fresh culture dishes. The process of re- plating or sub culturing the cells is repeated many times and for many months. Each cycle of subculturing the cells is referred to as a passage. Once the cell line is established, the original cells yield millions of embryonic stem cells. Embryonic stem cells that have proliferated in cell culture for six or more months without differentiating, are pluripotent, and appear genetically normal are referred to as an embryonic stem cell line. At any stage in the process, batches of cells can be frozen and shipped to other laboratories for further culture and experimentation $^{31}$.

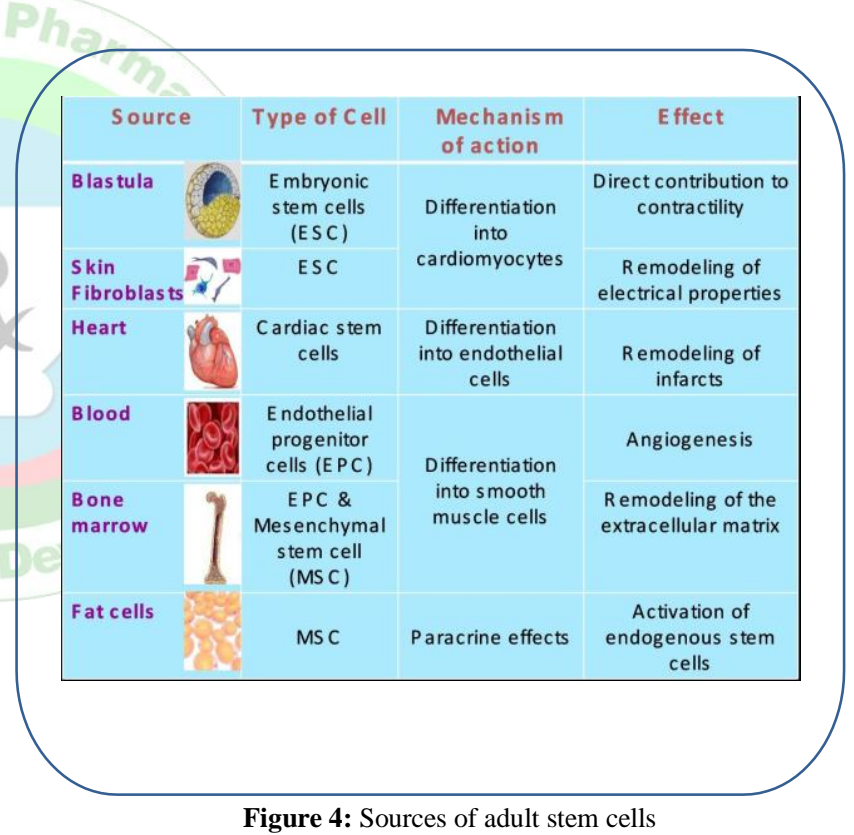

\section{Stem Cell Lines}

A stem cell line is a family of constantly dividing cells, the product of a single parent group of stem cells. They are obtained from human or animal tissues and can replicate for long periods of time in vitro ("within glass"; or, commonly, "in the lab", in an artificial environment). They are frequently used for research relating to embryonic stem cells or cloning entire organism. Once stem cells have been allowed to divide and propagate in a controlled culture, the collection of healthy, dividing, and undifferentiated cells is called a stem cell line ${ }^{32}$. 


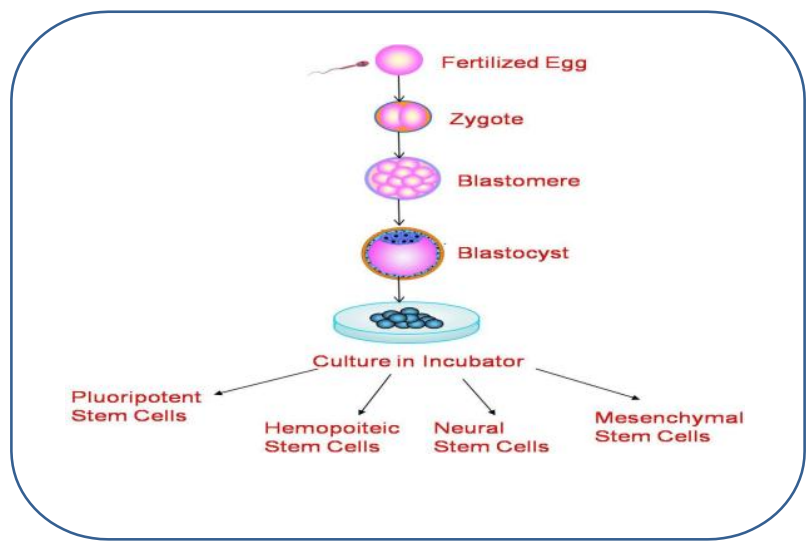

Figure 5: Stem cell culture and stem cell lines

Table 2: Overview of risk factors and risks associated with stem cell-based therapy ${ }^{33}$ :

\begin{tabular}{|c|c|c|}
\hline & 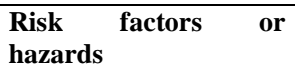 & Identified risks \\
\hline 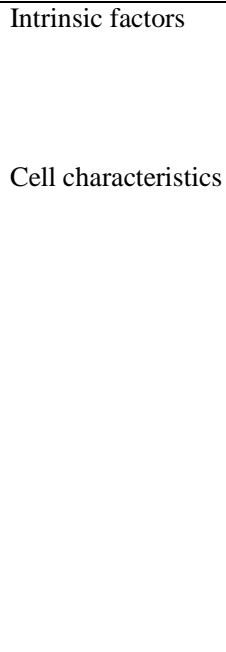 & $\begin{array}{l}\text { Origin of cells (e.g. } \\
\text { autologous vs. allogenic, } \\
\text { diseased vs. healthy } \\
\text { donor/tissue) } \\
\text { Differentiation status } \\
\text { Tumourigenic potential } \\
\text { Proliferation capacity } \\
\text { Life span } \\
\text { Long term viability - } \\
\text { Excretion patterns (e.g. } \\
\text { growth factors, } \\
\text { cytokines, chemokines) }\end{array}$ & $\begin{array}{ll}\text { - } & \text { Rejection of cells } \\
\text { - } & \begin{array}{l}\text { Disease } \\
\text { susceptibility }\end{array} \\
\text { - } & \text { Unwanted } \\
\text { biological effect } \\
\text { (e.g. in vivo } \\
\text { differentiation in } \\
\text { unwanted cell } \\
\text { type) } \\
\text { Toxicity } \\
\text { - Neoplasm } \\
\text { formation } \\
\text { (benign or } \\
\text { malignant }\end{array}$ \\
\hline $\begin{array}{l}\text { Extrinsic factors } \\
\text { Manufacturing and } \\
\text { handling }\end{array}$ & $\begin{array}{l}\text { - Lack of donor history } \\
\text { - Starting and raw } \\
\text { materials } \\
\text { - Plasma derived } \\
\text { materials } \\
\\
\text { - Contamination by } \\
\text { adventitious agents } \\
\text { (viral/bacterial/ } \\
\text { mycoplasma/fungi, } \\
\text { prions, parasites) } \\
\text { - Cell handling } \\
\text { procedures (e.g. } \\
\text { procurement) } \\
\text { - Culture duration } \\
\text { - Tumourigenic } \\
\text { potential (e.g. culture } \\
\text { induced } \\
\text { transformation, } \\
\text { incomplete removal } \\
\text { of undifferentiated } \\
\text { cells) } \\
\text { - Non cellular } \\
\text { components } \\
\text { - Pooling of allogenic } \\
\text { cell populations - }\end{array}$ & 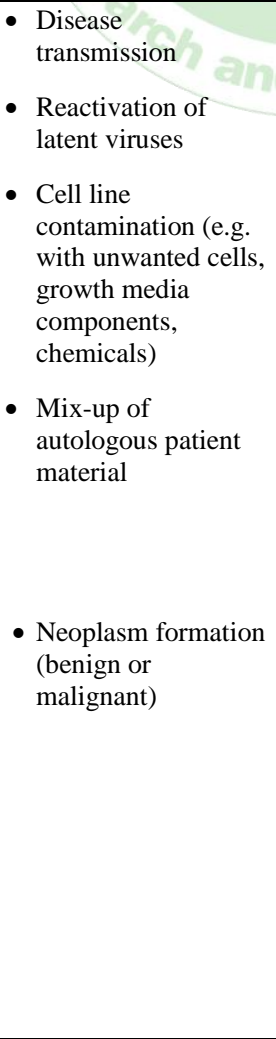 \\
\hline
\end{tabular}

\begin{tabular}{|c|c|c|}
\hline & $\begin{array}{l}\text { Conservation (e.g. } \\
\text { cryopreservatives) } \\
\text { - Storage conditions } \\
\text { (e.g. failure of } \\
\text { traceability, human } \\
\text { material labelling) } \\
\text { - Transport conditions }\end{array}$ & \\
\hline $\begin{array}{l}\text { Clinical } \\
\text { characteristics }\end{array}$ & $\begin{array}{l}\text { - Therapeutic use (i.e. } \\
\text { homologous or non- } \\
\text { homologous) } \\
\text { - Indication } \\
\text { - Administration route } \\
\text { - Initiation of immune } \\
\text { responses } \\
\text { - Use of immune } \\
\text { supressives } \\
\text { - Exposure duration } \\
\text { - Underlying disease } \\
\text { - Irreversibility of the } \\
\text { treatment }\end{array}$ & $\begin{array}{l}\text { - Undesired immune } \\
\text { response (e.g. } \\
\text { GVHD) } \\
\text { - Unintended } \\
\text { physiological and } \\
\text { anatomical } \\
\text { consequences (e.g. } \\
\text { arrhythmia) } \\
\text { - Engraftment at } \\
\text { unwanted location } \\
\text { - Toxicity } \\
\text { - Lack of efficacy } \\
\text { - Neoplasm } \\
\text { formation (benign } \\
\text { or malignant) }\end{array}$ \\
\hline
\end{tabular}

\section{Stem Cell Transplant Side EfFects ${ }^{35}$ :}

\section{Mouth and throat pain:}

Mucositis (inflammation or sores in the mouth) is a shortterm side effect that can happen with chemo and radiation. It usually gets better within a few weeks after treatment, but it can make it very painful to eat and drink.

\section{Nausea and vomiting}

Because chemotherapy drugs can cause severe nausea and vomiting, doctors often give anti-nausea medicines at the same time as chemo to try and prevent it

\section{Infection}

During about the first 6 weeks after transplant, until the new stem cells start making white blood cells (engraftment), you can easily get serious infections. Bacterial infections are most common during this time, but viral infections that were controlled by your immune system can become active again. Fungal infections can also be an issue.

\section{Bleeding and transfusions}

After transplant, you're at risk for bleeding because the conditioning treatment destroys your body's ability to make platelets.

\section{Bleeding and transfusions}

After transplant, you're at risk for bleeding because the conditioning treatment destroys your body's ability to make platelets. 


\section{Graft-versus-host disease}

Graft-versus-host disease (GVHD) can happen in allogeneic transplants when the immune cells from the donor see the recipient's body as foreign.

\section{Acute GVHD}

Acute GVHD can happen 10 to 90 days after a transplant, though the average time is around 25 days.

The first signs are usually a rash, burning, and redness of the skin on the palms and soles. This can spread over the entire body. Other symptoms can include:

- Nausea

- Vomiting

- Stomach cramps

- Diarrhea (watery and sometimes bloody)

- Loss of appetite

- Yellowing of the skin and eyes (jaundice)

- Abdominal (belly) pain

- Weight loss

\section{Chronic GVHD}

Chronic GVHD can start anywhere from about 90 to 600 days after the stem cell transplant.

In severe cases, the skin may blister and peel, like bad sunburn. A fever may also develop. Other symptoms of chronic GVHD can include:

- Decreased appetite

- Diarrhea

- Abdominal (belly) cramps

- Weight loss

- Yellowing of the skin and eyes (jaundice)

- Enlarged liver

- Bloated abdomen (belly)

- Pain in the upper right part of the abdomen (belly)

- Increased levels of liver enzymes in the blood (seen on blood tests)

- The skin feels tight

- Dry, burning eyes

- Dryness or painful sores in the mouth

- Burning sensations when eating acidic foods

- Bacterial infections

- Blockages in the smaller airways of the lungs

\section{Hepatic veno-occlusive disease (VOD)}

Hepatic veno-occlusive disease (VOD) is a serious problem in which tiny veins and other blood vessels inside the liver become blocked. It's not common, and it only happens in people with allogeneic transplants, and mainly in those who got the drugs busulfan or melphalan as part of conditioning.

\section{Graft failure}

Grafts fail when the body does not accept the new stem cells (the graft). The stem cells that were given do not go into the bone marrow and multiply like they should. Graft failure is more common when the patient and donor are not well matched and when patients get stem cells that has had the Tcells removed. It can also happen in patients who get a low number of stem cells, such as a single umbilical cord unit. Still, it's not very common.

\section{Transplant problems that may show up later}

Possible long-term risks of transplant include:

- Organ damage

- Relapse (the cancer comes back)

- Secondary (new) cancers

- Abnormal growth of lymph tissues

- Infertility (the inability to produce children)

- Hormone changes, such as changes in the thyroid or pituitary gland

- Cataracts (clouding of the lens of the eye, which causes vision loss)

\section{Cancer relapse}

The goal of a stem cell transplant in cancer is to prolong life and even cure the cancer. But in some cases, the cancer comes back (relapses). Relapse can happen a few months to a few years after transplant. It happens much more rarely 5 or more years after transplant.

\section{PRECAUTIONS ${ }^{36}$ :}

\section{Infections:}

Here are a few general tips to keep from getting an infection:

- Wash your hands often with antibacterial soap and water or clean them with an alcohol-based hand sanitizer.

- Stay away from people who are sick or have recently been sick.

- Wear a mask while you're in public or if you may be near strangers (if your transplant team asks you to).

The following things can be a sign of infection. Call your doctor's office right away if you have:

A fever of $100.4^{\circ} \mathrm{F}\left(38.0^{\circ} \mathrm{C}\right)$ or higher.

Don't take acetaminophen $\left(\right.$ Tylenol $\left.^{\circledR}\right)$ unless your healthcare provider tells you to.

You don't have to take your temperature every day. But, check it regularly if you don't feel well.

- Flushed (red, warm-feeling) skin, sweating, or shaking chills.

- Coughing, sneezing, runny nose, shortness of breath, or chest discomfort.

- Redness, swelling, or pain in your throat, eyes, ears, skin, joints, or abdomen (belly).

- Blurred vision or other changes in your ability to see clearly.

- Frequent urination (peeing), a burning feeling while you urinate, or both.

- Irritation in your rectum, including burning and pain.

- A rash.

- Small blisters, similar to cold sores, around your mouth or on any other part of your body.

- Trouble flushing your tunnelled chest catheter, if you have one.

- Chills while or after flushing your tunnelled chest catheter, if you have one. 


\section{Personal Hygiene}

\section{Shower or bathe every day.}

- Use a mild soap, such as Dove ${ }^{\circledR}$ or Caress ${ }^{\circledR}$. Don’t use Ivory $^{\circledR}$ or a deodorant soap. They can dry out your skin.

- Be sure to wash your underarms and groin.

- Use a washcloth and towel that are only for your personal use.

- If your skin is dry, don't use very hot water. Apply baby oil or a skin moisturizer, such as Eucerin ${ }^{\circledR}$ or $\mathrm{CeraVe}^{\circledR}$. Put it on after you bathe, while your skin is still damp. Gently pat your skin dry with your towel. Don't use lotions containing alcohol. They will make your skin drier.

- Limit your time in direct sunlight. Your skin will be more sensitive and may burn more easily after your transplant. The medications you're taking may add to this.

- Whenever you're in the sun, protect your skin with a sunblock that has an SPF of at least 30. Reapply it often.

- If you will be in direct sunlight for 20 minutes or longer, cover your skin with cotton clothing and a protective hat. Being in the sun for a long time may also reactivate cold sores (herpes simplex virus).

- You can wear contact lenses, but make sure that they're cleaned well before you put them in. Don't reuse cleaning solution. Be sure to throw cleaning solutions away when they expire. If your eyes are dry, use moisturizing drops.

- You can wear makeup, but buy all new products after your transplant.

- New nails will grow and replace your old nails. This will happen gradually over 3 to 4 months after your transplant. Don't get a manicure or pedicure in a nail salon while your immune system is still recovering. You can do this at home with your own equipment.

- If you still have a tunnelled catheter, don't let it soak in water while you bathe. Read the resource About Your Tunneled Catheter for more information.

- Don't get body piercings or tattoos after your transplant. These increase your risk of hepatitis and other infections.

- Hair usually starts to grow back about 3 months after the transplant. It's possible that your hair may grow back with a different texture. Although it's rare, hair loss can happen months or years after the transplant.

\section{Mouth Care}

This will be when your absolute neutrophil count (ANC) is higher than 500 (sometimes called 0.5) and your platelet count is 20,000 (sometimes called 20) or higher.

\section{Caring for your Tunnelled Catheter}

It's just as important to keep your tunnelled catheter clean after you leave the hospital as it was while you were in the hospital.

Call your doctor's office right away if:

- You have redness, swelling, or drainage around the area where the catheter exits your body

- Your needleless connector falls off

- You have a fever of $100.4^{\circ} \mathrm{F}\left(38^{\circ} \mathrm{C}\right)$ or higher or chills

- You have a break or leak in your catheter

- You have an unexplained problem with your catheter

Your Home Environment

Keep your home as free of dirt and dust as possible. But, don't go to extremes. For example, don't repaint your walls or put down new carpets.

Don't be around any renovations or construction until your transplant team tells you its okay. This includes those in process and those done within the past 3 months.

Stay out of musty areas where mold might grow, such as a damp basement. You can use an air filtration system in your home, but you don't need to.

Don't use a humidifier. Bacteria and mold grow easily in it. A pan of water placed near a heat source may help in the winter. If you do this, change the water every day.

In general, try not to do any chores like dusting or vacuuming for the first 3 months after your transplant. Depending on your energy level, it's fine for you to cook, wash dishes, or iron.

Keep your bathroom very clean, especially the tub and toilet. Make sure it's cleaned with a disinfectant regularly. It's best for someone else to do this chore.

Wash your eating utensils, towels, and linens carefully. They don't need to be washed separately from the rest of your household.

Thoroughly wash all forks, spoons, and knives with hot water and dishwashing detergent or use a dishwasher.

Wash towels twice a week and bed linens once a week. Use only your own towels and washcloths, not those of your family members.

You can have household plants in your home. But, for the first few months after your transplant:

Don't touch the soil from household plants unless you wear gloves and a mask.

Don't touch the water in a vase of flowers. Someone else should change the water in the vases daily.

\section{Pets}

- If you have a cat or dog at home, follow the additional guidelines below until your doctor gives you other instructions.

- Make sure your pet is up-to-date with immunizations and booster shots. 
- Have your veterinarian check your pet's stool for parasites every year.

- If you have a cat, get it tested for feline leukaemia and toxoplasmosis every year.

- Have your pet treated for fleas. If your pet walks through wooded areas, have it screened for ticks every day during tick season (May to November). Talk with your pet's veterinarian about using a flea and tick collar.

- Don't clean cat litter boxes or clean up after your dog. Have someone else do these things for you.

- Keep your pets indoors or on your own property whenever you can. This is to help keep them from picking up diseases from other animals.

- Don’t allow pets in your bed.

- Outside of your home, avoid close contact with animals in a farm or a petting zoo.

\section{Family and Visitors}

You can have visitors, but limit them to small groups. Don't visit with anyone who has:

- A cold.

- Chickenpox.

- Recently been exposed to chickenpox.

- Recently been exposed to the herpes simplex virus (the virus that causes cold sores and genital sores).

- Recently been exposed to shingles.

- Recently been exposed to any other type of virus or infection.

- Recently received a vaccine with a live virus, such as varicella (the chicken pox virus) or rotavirus. There are very few of these, but if someone in your household needs one, tell their doctor that you're immune suppressed and live in the same household.

\section{Outside your home}

Take regular walks outside, but avoid dirty areas and construction sites. Walking is an excellent way to regain your strength and endurance

Avoid taking public transportation (such as a train or bus) for at least 3 months after your transplant. We understand you may need to take a taxi, car service, or other transportation such as Access-a-Ride to return for follow-up visits. Don't swim in lakes, rivers, or public or crowded pools until your immune system has recovered.

\section{Don't swim if your tunnelled catheter is still in place.}

\section{Bleeding}

Platelets are blood cells that help form clots and control bleeding. When your platelet count is low, you're at risk for bleeding

If you have an injury that causes bleeding, don't panic. Stay calm and follow the guidelines below for the type of injury.

Open wounds: If you cut yourself, put a clean, dry gauze pad, towel, or cloth over the cut. Press it firmly. Keep pressing until the bleeding stops. If the bleeding doesn't stop, elevate the wound. For example, raise your arm or prop up your feet. Apply ice to the wound and call your doctor.

Nosebleeds: If you have a nosebleed, sit up and lean forward slightly. Don't tilt your head back. Squeeze the bridge of your nose firmly between your thumb and forefinger for at least 10 minutes without letting go. If the bleeding doesn't stop, keep squeezing your nose. Apply a small bag of ice to the bridge of your nose until the bleeding stops. If the bleeding continues longer than 30 minutes, call your doctor.

Accidents: If you're in an accident, you may need blood or blood products. They should be irradiated to 3,000 rads. This is to keep transfused blood from causing GVHD.

Wear your Medic Alert jewelry at all times. It gives the doctor who will be treating you this information.

If you're admitted to another hospital, have the doctor call Memorial Sloan Kettering (MSK) right away for guidelines on blood products.

If your platelet count is below 50,000(50), follow the guidelines below.

Use an electric razor when shaving.

Use a soft-bristle toothbrush or an oral irrigator such as a Water Pic $^{\circledR}$ to keep your gums from bleeding. Don't use dental floss.

Don't take aspirin, products that have aspirin, or nonsteroidal anti-inflammatory drugs (NSAIDs) such as ibuprofen $\left(\right.$ Advil $\left.^{\circledR}\right)$ or naproxen $\left(\right.$ Aleve $\left.^{\circledR}\right)$. For more information, read the section "Common Medications to Avoid."

You can blow your nose, but don't blow it forcefully.

If you're constipated, call your doctor. You may need more fiber in your diet or a stool softener.

Avoid activities or sports that can cause injury. If you have questions or concerns about this, talk with your doctor.

\section{Resuming Your Activities}

Daily activities

The time it takes to recover after a transplant varies. It usually takes about 3 months, but it's also normal to take more or less time.

\section{Exercise}

It will probably take time for you to regain your strength. It may be helpful to follow a regular exercise plan. When you start to exercise, start with easy exercises.

\section{Hobbies}

Some hobbies, such as woodworking, painting, and model building, use products that can be toxic. Always work in a room with plenty of fresh air. Keep the windows open. Use nontoxic paints and glue

\section{Returning to school or work}

The earliest you can go back to school or work is 2 to 4 months from the time of your transplant. This time frame can vary from person to person and depends on many things. 


\section{Travelling}

For the first 3 months after the day of your transplant, stay within about 1 hour of MSK.

\section{Sexual Health}

Before you go home, ask your doctor about resuming sexual activity. It's important for you and your partner to have answers to your questions

\section{Information for Women}

After your transplant, you may have:

Fewer menstrual periods

No menstrual periods

Dryness and discomfort of your vagina and vulva (the area outside your vagina)

Vulvovaginal moisturizers can help relieve dryness and discomfort of your vagina and vulva. They don't contain any hormones and are available without a prescription in most drug stores or on the Internet. Examples are vitamin $\mathrm{E}$ capsules, Replens ${ }^{\circledR}$, Hyalo $\mathrm{GYN}^{\circledR}$, and $\mathrm{K}-\mathrm{Y}^{\circledR}$ Brand LIQUIBEADSTM. Talk with your BMT doctor before using these products.

\section{Information for Men}

You may have lowered sexual desire after your transplant. This could have an impact on your relationship. However, as you regain your strength and increase your activities, your sexual desire should also increase.

You may also have erectile dysfunction (ED) after your transplant. ED can be treated with medication, such as sildenafil citrate $\left(\right.$ Viagra $\left.^{\circledR}\right)$ or tadalafil $\left(\right.$ Cialis $\left.{ }^{\circledR}\right)$. There are many other ways to treat ED.

\section{Drinking Alcohol and Using Tobacco}

After your transplant, your organs need time to recover. Alcohol can harm your liver and recovering bone marrow. This harm can be worse if you're taking medications that can affect your liver. Don't drink alcohol until your doctor tells you it's safe.

Never smoke:

- Cigarettes

- Cigars

- Marijuana

- Other tobacco products

Doing so can lead to a serious lung infection. It can also increase your risk of a second cancer.

\section{Follow-Up Care}

Your follow-up visits will be scheduled before you're discharged. Your doctor will decide how often you will need these visits. If you're doing well, they will be scheduled further apart.

\section{Vaccines and Immunization}

After your transplant, you will lose the protection from the vaccines you got as a child. This means you will need to get your childhood vaccines again once your immune system has recovered. This usually happens about 1 year after your transplant.

\section{CONCLUSION:}

In conclusion, stem cell therapy is the future of regenerative medicine and more research is needed to understand the exact biology and the therapeutic potential of stem cells. Stem cell-based treatment is exciting, that most likely benefit the human health. In this rapidly growing field, the potential to develop innovative stem cell-based therapies is indeed very attractive. Although such therapies evolve in a scientific and ethical manner, unregulated stem cell treatments are already being offered by many hospitals around the world. Therapeutics in the form of Bone Marrow Transplant (BMT), Skin replacement, Organ development, replacement of lost tissues such as hair, tooth, retina \& cochlear cells much more needed.

\section{ABREVATIONS:}

ESC - Embryonic Stem Cells

iPSC - Induced Pluripotent Stem Cells

HLA - Human Leukocyte Antigens

SSCs - Somatic Stem Cells

MSC - Mesenchymal Stem Cells

MHC -Major Histocompatability Complex

HLA - Human Leukocyte Antigen

FDA - Food Drug Administration

BMT - Bone Marrow Transplant

CRPF - Christopher Reeve Paralysis foundation

LVEF - Left Ventricular Ejection Function

AIIMS - All India Institute of Medical Sciences

HIV - Human Immunodeficiency Virus

AIDS - Acquired Immuno Deficiency Syndrome

hESC - Human Embryonic Stem Cells

VOC - Veno Occlusive Disease

SPF - Sun Protection Factor

ANC - Absolute Neutrophil Count

GVHD - Graft Virus Host Disease

MSK - Memorial Sloan Kettering

NSAIDS - Non Steroidal Anti-Inflammatory Drugs

ED - Erectile Dysfunction

\section{REFERENCES:}

1. Kalra K and Tomar PC, Stem Cell: Basics, Classification and Applications. American Journal of Phytomedicine and Clinical Therapeutics, AJPC.2014; 2(7)919-930

2. Hans R. The potential of stem cells: An inventory. Human biotechnology as Social Challenge, England, Ashgate Publishing, Ltd. 2007; 28.

3. www.medicalnewstoday.com/info/stem_cell.

4. www.findingtruthmatters.org/articles/stem- cell.

5. Jesse K. Biehl, BS, Brenda Russell Introduction to Stem Cell Therapy, J Cardiovasc Nurs. 2009; 24(2):98-105.

6. Laflamme MA, Chen KY, Naumova AV, et al. Cardiomyocytes derived from human embryonic stem cells in pro-survival factors enhance function of infracted rat hearts. Nat Biotechnol. 2007; 25(9):1015-24.

7. Wernig $\mathrm{M}$, Zhao JP, Pruszak J, et al. Neurons derived from reprogrammed fibroblastfunctionally integrate into the fetal brain and improve symptoms of rats with parkinson's disease. Proc Natl Acad Sci USA. 2008; 105(15):5856-61

8. Darabi R, Gehlbach K, Bachoo RM, et al. Functional skeletal muscle regeneration from differentiating embryonic stem cells. Nat Med. 2008; 14(2):134-43.

9. Laflamme MA, Gold J, Xu C, et al. Formation of human myocardium in the rat heart from human embryonic stem scells. Am J Pathol. 2005; 167(3):663-71.

10. Kehat I, Khimovich L, Caspi O, et al. Electromechanical integration of cardiomyocytes derived from human embryonic stem cells. Nat Biotechnol. 2004; 22(10):1282-89. 
11. Xue T, Cho HC, Akar FG, et al. Functional integration of electrically active cardiac derivatives from genetically engineered human embryonic stem cells with quiescent recipient ventricular cardiomyocytes: insights into the development of cell-based pacemakers. Circulation. 2005; 111(1):11-20.

12. Engler AJ, Sen S, Sweeney HL, Discher DE. Matrix elasticity directs stem cell lineage specifications. Cell. 2006; 126(4):677-89.

13. Alhadlaq A, Mao JJ. Tissue-engineered osteochondral constructs in the shape of an articular condyle. J Bone Joint Surg Am. 2005; 87(5):93644.

14. I. Singec, R. Jandial, A. Crain, G. Nikkhah and E.Y. Snyder, "The leading edge of stem cell therapeutics". Annu. Rev. Med. 58, 2007; 313-328.

15. C. Jahoda. And A. Reynolds, "Skin stem cells - a hairy issue." Nature Medicin,e 2000; 6:1095-1097.

16. Freed CR, Greene PE, Breeze RE, W-Y Tsai, W. Du Moucel, R. Kao, S. Dillon, H. Winfield, S. Culver, J.Q. Trojanowski, D. Eidelberg and S. Fahn, "Transplantation of embryonic dopamine neurons for severe parkinson's disease" New England J. of. Med.2000; 344:710-719.

17. N. Lumelsky, O. Blondel, P. Laeng, I. Velasco, R. Ravin and R. McKay, "Differentiation of embryonic stem cells to insulin-secreting structures similar to pancreatic islets" Science,2001; 292:1389- 1394.

18. Kumar S, Singh NP, Stem cells: A new paradigm Indian Journal of Human Genetics, 2006; 12(1).

19. Okano H, Okada S, Nakamura M. Neural stem cells and regeneration of injured spinal cord. Kidney Int 2005; 68:1927-31.

20. Wollaret KC. BOOST trial (Bone marrow transfer to en- hance STelevation infarct). Lancet 2004; 364.

21. Mathur A, Martin JF. Stem cells and repair of the heart. Lancet 2004;
364:183-92.

22. Monogr. Stem cell and HIV infection. J Natl Cancer Inst 2000; 28:249.

23. Jeffrey MK, Ponzetti M, David SA, stem cells An Interactive Qualifying Project Report, Submitted to the Faculty of worcester polytechnic institute In partial fulfillment of the requirements for the Degree of Bachelor of Science, 2006. AJPCT, 2014; 2(7):919-930.

24. S. Avasthi, R. N. Srivastava, A. Singh and M. Srivastava "Stem cells: Past, Present, Future - a review article", Internaet J. Med. Update, 2008, 3(1):2230.

25. juanv.files.wordpress.com/../stemcells2-gif.

26. www.nature.com/.../images/nature06800- f2.2.jpg

27. Schöler HR, "The Potential of Stem Cells: An Inventory". In Nikolaus Knoepffler, Dagmar Schipanski, and Stefan Lorenz Sorgner. Humanbiotechnology as Social Challenge. Ashgate Publishing, Ltd. $2011 ; 1: 380$.

28. Ulloa-Montoya L, Verfaillie CM, and W.S Hu, "Culture systems for pluripotent stem cells". J Biosci Bioeng, 2005; 100(1):12-27.

29. www.kumc.edu/stemcell/images/stemce llscomefrom.jpg

30. http://gslc.genetics.utah.edu/units/stemcells/sc create

31. Carla A Herberts1, Marcel SG Kwa, Harm PH Hermsen1 Risk factors in the development of stem cell therapy Herberts et al. Journal of Translational Medicine 2011; 9:29.

32. www.cancer.gov/about-cancer/treatment/types/stem-cell-transplant\#2

33. www.cancer.org/treatment/treatments-and-side-effects/treatmenttypes/stem-cell-transplant/transplant-side-effects.

34. www.mskcc.org/cancer-care/patient-education/returning-home-afteryour-autologous-stem-cell-transplant.

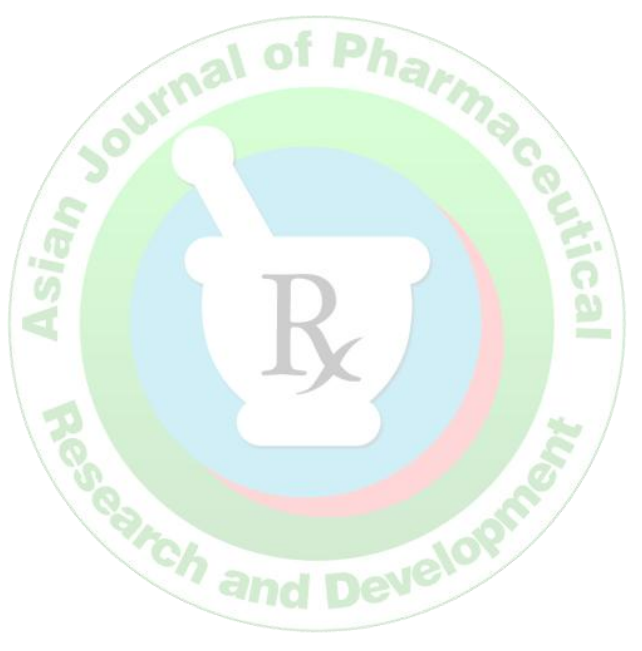

